\section{Germany edges towards law}

Bonn

REPRESENTATIVES of some 25 interest groups delivered their responses to a draft 'basic law' to regulate genetic engineering at a closed hearing in the West German Health Ministry last week.

The government has made the ambitious promise that it will pass the completed law by the end of 1990 , when a new parliament will be elected. But basic research scientists, worried about the potential consequences of the law, are pressing the government for changes before it takes effect.

Science organizations, trades unions, industry and ecology groups were represented at the ministry meeting. Their views will be taken into account when the ministry presents the draft to the cabinet, which is expected to approve it by 27 June and send it to the upper house of parliament, the Bundesrat, for a vote. The lower house, or Bundestag, will begin debating the law in the autumn.

The new law, which has been in discussion for nearly five years (see Nature 336, 611 ; 1988), is a "framework" for more detailed industrial production using recombinant DNA and the release of genetically modified organisms into the environment.

The law will give legal status to the current mechanisms for self-regulation of genetic engineering. These mechanisms include a central body (the "Central Commission for Biological Safety" or ZKBS in German) to evaluate applications to perform recombinant DNA experiments; four "security levels" for experiments with pathogenic bacteria; and regulations for release. Matters newly covered by the law include a provision for public participation in the licensing procedure and criminal penalties for breaking the rules.

Basic research organizations have begun reluctantly to accept that the law is inevitable and are trying now to shape the legislation to defend their interests.

Researchers object most strongly to two aspects of the draft law: the regulations concerning pathogenic bacteria and the composition and role of the ZKBS. The draft calls for the registration with the Länder (states) of "non-pathogenic organisms" and "safety strains" which do not present a risk to laboratory personnel or the population. Pathogenic organisms that present a moderate to significant risk must be individually registered with the Federal Health Office.

Ernst-Ludwig Winnacker, vice-president of the Deutsche Forschungsgemeinschaft (DFG), pleaded at the Health Ministry hearing for a removal of registration for the first group of organisms and for a general - rather than individual - licensing procedure for the least dangerous of the second group. Some laboratories would need to file "fifteen hundred applications a year" to meet this requirement, said Winnacker, a situation that would be "ridiculous".

Researchers also objected to the stated purpose of the law: to protect people and the environment from "the dangers of genetic engineering". Klaus Fleischmann, Executive Secretary of the organization of German National Research Centres (Grossforschungseinrichtungen) protested that the dangers of the environmental release of genetically modified organisms are no worse than the dangers of the release of their unmodified precursors.

Both Winnacker and Fleischmann favour a centralized licensing procedure carried out by ZKBS rather than by the Länder. Most of the cabinet are likely to support them in this, but they will probably be opposed by the Federal Environment Ministry as well as the

\section{London}

A NATIONAL register of DNA profiles may be created within 2 to 5 years, according to the British government's Home Office. Responding to a report from the House of Commons Home Affairs Committee on the national Forensic Science Service, the government announced last week that work is now under way in the Central Research Support Establishment to prepare a computer program suitable for a database of DNA profiles. By the time this is ready, it is hoped that consensus may have been reached on a standard technique for DNA fingerprinting and on the legal and ethical questions relating to the creation of the database.

Since 1987, when DNA fingerprinting was developed by Professor Alex Jeffreys of the University of Leicester, the technique has been used in 200 court cases leading to criminal conviction. The technique is carried out for the criminal courts only by the Forensic Science Service. ICI, the only private laboratory to use the technique, can do so only for civil cases, such as immigration or paternity disputes, as well as for overseas police forces.

At present the law requires that an individual must give consent before a sample can be taken for use in a DNA test. A police officer of at least the rank of superintendent must authorize the taking of the sample, and only if there are grounds for believing that the accused person has been involved in a serious arrestable offence and that the sample could confirm or disprove his involvement.

Länder. Environment Minister Klaus Töpfer (Christian Democrat) has already objected to the draft law as it reduces the regulatory power of his ministry.

The Länder are expected to recommend changes in the law when it reaches the Bundesrat. In addition to trying to gain as much regulatory power as possible, the Länder are expected to insist, as will the opposition Social Democrats in the Bundestag, that there be more public participation in the licensing procedure.

West German industry, which has been pushing hard for the law, is basically satisfied with the draft, as is the trade union IG Chemie - representing chemical industry workers. The union fears that many jobs will be lost if the biotechnology industry continues the exodus from West Germany that it fears has already begun. Other unions represented by the umbrella labour organization DGB (Deutsche Gewerkschaftsbund) take a much more sceptical view of the law, taking a position one observer at the Health Ministry hearing called "very Green".

Steven Dickman

\title{
Profiles bank on the way
}

But the committee argues that the law should be changed. "Provided the level of invasion of privacy is acceptably low", it said, there is no objection to making it a legal requirement to provide a sample for a DNA test.

The forensic service, which runs six laboratories on a budget of $£ 12$ million a year, was severely criticized in the Home Affairs Committee report, which found it remarkable that the scientific standards and reputation of the service remain high, since it "had fallen on hard times". It could not meet the demand for its work, was losing some of its best staff, and morale was at rock bottom.

The government accepted the criticisms, but says that "not all can be quickly solved". Since publication of the report in February, though, "a good deal has been done to meet the problems identified". A new director-general has been appointed, staff increases are planned and pay has been improved, says the government.

The government has made no commitment to increase resources for the overstretched Forensic Science Service. Instead, it says that the service should be funded not directly through the Home Office but through the police, who would be able to judge the value of the Service to them and thus the resources they are prepared to commit to it. The service is also under consideration for the status of an "executive agency", which would make it more independent from government, and free to carry out private work.

Christine McGourty 